\title{
The impact of Paleocene/Eocene boundary events on middle neritic benthic foraminiferal assemblages from Egypt
}

\author{
R.P. Speijer ${ }^{\text {a,1 }}$, G.J. van der Zwaan ${ }^{a}$, B. Schmitz ${ }^{b}$ \\ ${ }^{a}$ Department of Geology, Institute of Earth Sciences, Utrecht University, P.O. Box 80.021, 3508 TA Utrecht, The Netherlands \\ 'Department of Marine Geology, Earth Sciences Centre, Göteborg University, S-413 81 Göteborg, Sweden
}

Received 16 January 1995; accepted 12 October 1995

\begin{abstract}
A $25 \mathrm{~m}$ upper Paleocene to lower Eocene marly sequence exposed at Gebel Duwi, (Quseir, Red Sea coast of Egypt) provides a good opportunity for studying Paleocene/Eocene (P/E) boundary stratigraphy and events. Various bio-, eco-, and isotope stratigraphic correlations accurately delineate the position of the $\mathrm{P} / \mathrm{E}$ boundary (i.e. the level of stable isotopic excursions and deep-sea benthic extinctions) in the middle part of this section, within Zones P5 and NP9. In this paper the impact of $\mathrm{P} / \mathrm{E}$ boundary environmental perturbations on benthic foraminiferal communities of the shallow Tethyan shelf is examined.

Benthic foraminiferal assemblages from Gebel Duwi, characterized by large Frondicularia phosphatica and $F$. nakkadyi in addition to a number of other neritic taxa, but without any typical outer neritic-bathyal taxa, suggest middle neritic $(75-100 \mathrm{~m}$ ) deposition throughout the studied interval and only minor relative sea-level variations (perhaps some 10-20 m). Across the boundary sea-level appears to have been stable. Yet, a distinct faunal turnover marks the $\mathrm{P} / \mathrm{E}$ boundary of this shallow site, which, in contrast to deep-sea records, is less abrupt, being preceded by a gradual diversity decrease starting some four meters below the boundary. Moreover, most exits are either local or just temporary and thus not true extinctions: many (Lazarus) taxa reappear at some point above the boundary, while all but one of the disappearing taxa are known from other lower Eocene neritic deposits in Egypt.

In general, benthic foraminiferal assemblages display low diversities and high dominance values (notably Anomalinoides aegyptiacus: up to 74\%), suggesting high levels of environmental stress at the sea-floor. In combination with occasionally very high $\mathrm{P} / \mathrm{B}$ ratio's (up to $98 \% \mathrm{P}$ ), and generally laminated sediments, the character of the benthic assemblage points to a strong influence of recurrent dysoxia and/or anoxia. We suggest that these resulted from surface eutrophication by (intermittent) coastal upwelling and reduced ventilation of the bottom environment. Although these conditions prevailed during most of the time-interval studied, they were most severe during the latest Paleocene and early Eocene when eutrophication intensified, and the organic carbon flux to the sea-floor increased. Enhanced atmospheric contrasts between the Tethys seaway and the African continent, resulting in intensified longshore tradewinds, may have controlled these changes.

At the $\mathrm{P} / \mathrm{E}$ boundary the bottom environment became minimally ventilated, perhaps due to reduced oxygen advection from deeper waters. Three meters above the boundary a succession of increasingly diverse assemblages indicate a gradual
\end{abstract}

\footnotetext{
${ }^{1}$ Present address: Department of Marine Geology, Earth Sciences Centre, Göteborg University, S-413 81 Göteborg, Sweden $\equiv$ ill: robert@gvc.gu.se).
} 